\title{
Relapsing polychondritis in Singapore: a case series and review of literature
}

\author{
Tyng Yu $\underline{\text { Chuah }}^{1}$, MRCP, Nai Lee $\underline{L u i}^{1,2,3}$, MRCP
}

INTRODUCTION This study aimed to describe the clinical presentation, treatment and outcome of patients with relapsing polychondritis (RP) who were seen at a large tertiary-care academic medical institution in Singapore.

METHODS The medical records of all patients diagnosed with RP at the Department of Rheumatology and Immunology, Singapore General Hospital, Singapore, between 2005 and 2013 were reviewed. The diagnosis of RP was made using the modified McAdam criteria.

RESULTS Ten patients were diagnosed with RP during the study period. Among these patients, five fulfilled the modified McAdam criteria and five were probable cases of RP. The most common clinical presentations were auricular chondritis $(n=9)$, episcleritis or scleritis $(n=5)$, and large airway involvement $(n=3)$. All of the patients received prednisolone. Five patients developed haematological disorders. Patients with both RP and haematological disorders had a longer duration of RP symptoms prior to diagnosis, compared to patients with RP who did not develop haematological disorders (average duration of symptoms 14.7 months vs. 4.2 months).

CONCLUSION The high frequency of patients with haematological malignancies in this series was unexpected. Myelodysplastic syndrome has been reported, but other haematological malignancies are rarely associated with RP. As the association between haematological malignancies and RP is currently unclear, the threshold for haematological/ lymphoproliferative screening should be lowered in patients with RP.

Keywords: autoimmune, haematological disorder, relapsing polychondritis, rheumatology

\section{INTRODUCTION}

Relapsing polychondritis (RP) is a rare immune-mediated condition, which is characterised by recurrent and progressive inflammation of cartilaginous structures and proteoglycan-rich structures. ${ }^{(1)}$ RP particularly affects the cartilaginous areas of the ears and nose, and it is not uncommon for the eyes, joints and respiratory tract to be affected as well. RP can occur in isolation or in association with other diseases. The objective of the present study was to describe the clinical presentation, treatment and outcome of patients with RP who were seen at a large tertiarycare academic medical institution in Singapore.

\section{METHODS}

Singapore General Hospital is a 1,700-bed tertiary-care academic medical institution in Singapore. In this study, we retrospectively reviewed the medical records of all patients diagnosed with RP at the Department of Rheumatology and Immunology between January 2005 and December 2013. The medical records that were retrieved and reviewed included information on both inpatient and outpatient visits.

The diagnosis of RP was made according to the modified McAdam criteria. (2) The McAdam criteria suggest that a diagnosis of RP is almost certain if at least three of the following six criteria are present: (a) bilateral auricular chondritis; (b) non-erosive seronegative inflammatory polyarthritis; (c) nasal chondritis; (d) ocular inflammation such as conjunctivitis, keratitis, scleritis/ episcleritis and uveitis; (e) respiratory tract chondritis such as inflammation of the laryngeal and/or tracheal cartilages; or $(f)$ cochlear and/or vestibular dysfunction such as neurosensory hearing loss, tinnitus and vertigo. According to the modified McAdam criteria, a diagnosis of RP can be made if one of the following criteria is fulfilled: (a) at least three of the clinical criteria stated in the McAdam criteria; (b) one or more of the McAdam criteria with positive histological confirmation; or (c) chondritis at two or more separate anatomic locations with response to steroids and/or dapsone.

The clinical presentation, laboratory results, treatment response and clinical outcome of the patients were recorded using a standardised data collection sheet; the collected data was then summarised. This study design received approval from the local institutional review board.

\section{RESULTS}

A total of ten patients with RP symptoms were seen at the Department of Rheumatology and Immunology, Singapore General Hospital, Singapore, during the study period. Five of these patients fulfilled the modified McAdam criteria, while the remaining five patients fulfilled only part of the diagnostic criteria and were thus classified as probable cases of RP. The average age of onset of RP was 48 (range 22-72) years and the average duration of follow-up was 3.5 years (range 17 months-7 years). The patients were all of Chinese ethnicity and the female-to-male ratio was 7:3. The clinical presentation, laboratory results, and therapy and clinical outcomes of the ten patients are summarised in Table I.

${ }^{1}$ Department of Rheumatology and Immunology, Singapore General Hospital, ${ }^{2}$ Duke-NUS Medical School, ${ }^{3}$ Yong Loo Lin School of Medicine, National University of Singapore, Singapore Correspondence: Dr Chuah Tyng Yu, Resident, Department of Rheumatology and Immunology, Singapore General Hospital, Outram Road, Singapore 169608. tyngyu.chuah@mohh.com.sg 
Table I. Summary of the clinical presentation, laboratory results, and therapy and clinical outcomes of the patients with relapsing polychondritis (RP) ( $\mathrm{n}=10)$.

\begin{tabular}{|c|c|c|c|c|c|c|}
\hline No. & $\begin{array}{l}\text { Age }(y r) / \\
\text { gender }\end{array}$ & $\begin{array}{l}\text { Presenting symptom/duration } \\
\text { before diagnosis ( } \mathrm{mth} \text { ) }\end{array}$ & Diagnosis* & Laboratory result ${ }^{+}$ & Treatment & Complication \\
\hline 1 & $72 / \mathrm{F}$ & $\begin{array}{l}\text { Auricular chondritis, } \\
\text { scleritis/1 }\end{array}$ & $\begin{array}{l}\text { Probable } \\
\text { RP }\end{array}$ & $\begin{array}{l}\text { ESR: } 102 \mathrm{~mm} / \mathrm{hr} \\
\text { CRP: } 24.5 \mathrm{mg} / \mathrm{L}\end{array}$ & Prednisolone & $\begin{array}{l}\text { Death; chronic } \\
\text { myelomonocytic } \\
\text { leukaemia } \\
\text { transformation } \\
\text { to acute myeloid } \\
\text { leukaemia in blast } \\
\text { crisis } 30 \text { mth after RP } \\
\text { symptoms }\end{array}$ \\
\hline 2 & $62 / M$ & $\begin{array}{l}\text { Auricular chondritis, } \\
\text { scleritis, urticarial } \\
\text { vasculitis, nasal } \\
\text { chondritis/18 }\end{array}$ & $\mathrm{RP}$ & $\begin{array}{l}\text { ESR: } 105 \mathrm{~mm} / \mathrm{hr} \\
\text { CRP: } 100.0 \mathrm{mg} / \mathrm{L}\end{array}$ & $\begin{array}{l}\text { Prednisolone, } \\
\text { MTX, } \\
\text { mycophenolate } \\
\text { mofetil, } \\
\text { azathioprine, } \\
\text { cyclosporin A }\end{array}$ & $\begin{array}{l}\text { MDS } 60 \text { mth after RP } \\
\text { symptoms }\end{array}$ \\
\hline 3 & $43 / F$ & $\begin{array}{l}\text { Auricular chondritis, } \\
\text { bronchomalacia, } \\
\text { arthritis/2 }\end{array}$ & $\mathrm{RP}$ & $\begin{array}{l}\text { ESR: } 137 \mathrm{~mm} / \mathrm{hr} \\
\text { CRP: } 109.0 \mathrm{mg} / \mathrm{L}\end{array}$ & $\begin{array}{l}\text { Prednisolone, } \\
\text { azathioprine }\end{array}$ & Nil \\
\hline 4 & $50 / F$ & $\begin{array}{l}\text { Auricular chondritis, } \\
\text { iritis } / 1\end{array}$ & $\begin{array}{l}\text { Probable } \\
\text { RP }\end{array}$ & Not available & $\begin{array}{l}\text { Prednisolone, } \\
\text { azathioprine, } \\
\text { mycophenolate } \\
\text { mofetil }\end{array}$ & $\begin{array}{l}\text { Underlying diffuse } \\
\text { large B-cell lymphoma } \\
\text { post-autologous } \\
\text { transplant } 11 \text { yr before } \\
\text { RP symptoms }\end{array}$ \\
\hline 5 & $22 / F$ & $\begin{array}{l}\text { Auricular chondritis, } \\
\text { laryngitis, arthritis } / 1\end{array}$ & $\mathrm{RP}$ & $\begin{array}{l}\text { ESR: } 171 \mathrm{~mm} / \mathrm{hr} \\
\text { CRP: } 7.0 \mathrm{mg} / \mathrm{L} \\
\text { ANA: } 1: 400\end{array}$ & $\begin{array}{l}\text { NSAIDs, MTX, } \\
\text { prednisolone }\end{array}$ & Nil \\
\hline 6 & $34 / F$ & $\begin{array}{l}\text { Auricular chondritis, } \\
\text { nasal chondritis, non-erosive } \\
\text { seronegative inflammatory } \\
\text { arthritis/12 }\end{array}$ & $\mathrm{RP}$ & $\begin{array}{l}\text { ESR: } 4 \mathrm{~mm} / \mathrm{hr} \\
\text { CRP: } 3.0 \mathrm{mg} / \mathrm{L}\end{array}$ & $\begin{array}{l}\text { Prednisolone, } \\
\text { HCQ, SSZ, S/C } \\
\text { MTX, anakinra, } \\
\text { cyclosporin A, } \\
\text { leflunomide, } \\
\text { tocilizumab }\end{array}$ & Nil \\
\hline 7 & $35 / F$ & $\begin{array}{l}\text { Auricular chondritis, } \\
\text { scleritis, arthritis/2 }\end{array}$ & $\mathrm{RP}$ & $\begin{array}{l}\text { ESR: } 28 \mathrm{~mm} / \mathrm{hr} \\
\text { CRP: } 3.7 \mathrm{mg} / \mathrm{L} \\
\text { ANA: } 1: 200\end{array}$ & $\begin{array}{l}\text { NSAIDs, MTX, } \\
\text { prednisolone, } \\
\text { azathioprine }\end{array}$ & Nil \\
\hline 8 & $72 / \mathrm{M}$ & $\begin{array}{l}\text { Scleritis, laryngotracheal } \\
\text { involvement/36 }\end{array}$ & $\begin{array}{l}\text { Probable } \\
\text { RP }\end{array}$ & $\begin{array}{l}\text { ESR: } 107 \mathrm{~mm} / \mathrm{hr} \\
\text { CRP: } 190.0 \mathrm{mg} / \mathrm{L}\end{array}$ & $\begin{array}{l}\text { Prednisolone, } \\
\text { azathioprine, } \\
\text { cyclosporin A }\end{array}$ & $\begin{array}{l}\text { Monoclonal } \\
\text { gammopathy of } \\
\text { unknown significance } \\
9 \text { yr after RP symptoms }\end{array}$ \\
\hline 9 & $52 / M$ & Auricular chondritis/4 & $\begin{array}{l}\text { Probable } \\
\text { RP }\end{array}$ & $\begin{array}{l}\text { ESR: } 121 \mathrm{~mm} / \mathrm{hr} \\
\text { CRP: } 32.0 \mathrm{mg} / \mathrm{L}\end{array}$ & $\begin{array}{l}\text { NSAIDs, } \\
\text { prednisolone, } \\
\text { colchicine for } \\
1 \mathrm{yr}\end{array}$ & $\begin{array}{l}\text { MDS } 10 \mathrm{mth} \text { after RP } \\
\text { symptoms }\end{array}$ \\
\hline 10 & $35 / F$ & Auricular chondritis/1 & $\begin{array}{l}\text { Probable } \\
\text { RP }\end{array}$ & $\begin{array}{l}\text { ESR: } 30 \mathrm{~mm} / \mathrm{hr} \\
\text { CRP: } 3.0 \mathrm{mg} / \mathrm{L}\end{array}$ & Prednisolone & Nil \\
\hline
\end{tabular}

*Diagnosis is based on the modified McAdam criteria. ${ }^{(2)}$ †Erythrocyte sedimentation rate (ESR) for male patients was considered elevated if it was $>10 \mathrm{~mm} / \mathrm{hr}$. ESR for female patients was considered elevated if it was $>20 \mathrm{~mm} / \mathrm{hr}$. C-reactive protein (CRP) concentration was considered elevated if it was $>9.0 \mathrm{mg} / \mathrm{L}$. ANA: antinuclear antibody; F: female; HCQ: hydroxychloroquine; M: male; MDS: myelodysplastic syndrome; MTX: methotrexate; NSAIDs: nonsteroidal anti-inflammatory drugs; S/C: subcutaneous; SSZ: sulfasalazine

The most common clinical presentation in our study cohort was auricular chondritis (9/10 patients, 90\%). The next most commonly affected organ was the eyes, with episcleritis and scleritis being the presenting complaint in five patients. Three patients had large airway involvement (two were diagnosed using bronchoscopy and one using computed tomography). One of the three patients with large airway involvement (Patient 3) developed severe bronchomalacia three years after the diagnosis and required continuous positive airway pressure support.
Inflammatory markers were generally elevated in the patients with RP. An elevated erythrocyte sedimentation rate (ESR) was observed in $80.0 \%$ of the patients at their first presentation, as well as during acute exacerbation. An elevated concentration of C-reactive protein (CRP) was present in $50.0 \%$ of patients at their first presentation.

All ten patients received courses of prednisolone at least once during their treatment; the maximum dose administered was $60 \mathrm{mg}$. The longest duration of steroid treatment was eight years 
(in Patient 3, who had features of bronchomalacia). Although three patients were treated with nonsteroidal anti-inflammatory drug (NSAID) monotherapy for a month, they were later switched to prednisolone due to a lack of response to the NSAID. All except one patient required second-line agents. The second-line agents used included azathioprine, methotrexate, cyclosporin A, mycofenolate mofetil, hydroxychloroquine, sulfasalazine and leflunomide. One patient (Patient 6) received anakinra, a biologic therapy, but was later initiated on tocilizumab every 4-6 weeks in view of the patient's poor response to the previous therapy. At the time of writing, this patient was still on tocilizumab every 4-6 weeks.

Five of the ten patients in this case series had haematological disorders. One patient (Patient 4) was diagnosed with diffuse large B-cell lymphoma 11 years before the diagnosis of RP, while the remaining four patients developed haematological disorders after the diagnosis of RP. In the latter four patients, the haematological disorder that developed was myelodysplastic syndrome (MDS). The patients with both RP and haematological disorders had a longer duration of RP symptoms prior to diagnosis, compared to the patients with RP who did not develop haematological disorders (average duration of symptoms 14.7 months vs. 4.2 months).

\section{DISCUSSION}

Interestingly, despite the multi-ethnic composition of Singapore's population (74.3\% Chinese, $13.4 \%$ Malay and $9.1 \%$ Indian), all of the patients with RP in the present study were of Chinese ethnicity. ${ }^{(3)}$ It is unclear whether the lack of representation of the other ethnic groups was related to ethnic-specific factors or the presence of selection bias. More female $(n=7)$ than male $(n=3)$ patients were affected in this case series, although previous series reported that RP occurs at the same frequency in both genders. ${ }^{(2)}$

The most common presenting feature in our case series was auricular chondritis, which was seen in nine out of the ten patients. In contrast, a case series conducted by Kong et al reported that airway complication was the most common presenting feature of RP in their Oriental population. ${ }^{(4)}$ Airway complications were seen in only three of our ten patients. One of these three patients developed severe bronchomalacia three years after the diagnosis of RP while on a tapering dose of prednisolone; this patient required home continuous positive airway pressure therapy. Nasal chondritis has been reported to be present in $61 \%$ of patients with RP over the course of the disease. ${ }^{(5)}$ However, this condition was only present in two of the patients in our case series, despite our study's relatively long duration of follow-up (the longest duration of follow-up was seven years). One of the patients in our series was pregnant when the RP was active, but the disease did not affect the baby. One case study, which was published in 1960, reported that the baby of a woman with RP was affected at birth. ${ }^{(6)}$

Eight of the ten patients in our case series had elevated ESR at presentation and during flare. Pearson et al reported raised ESR in $80 \%$ of their patients with RP. ${ }^{(7)}$ On the other hand, CRP levels were elevated in only five of the ten patients in our series. This suggests that ESR may be a more useful biomarker than CRP for the diagnosis and monitoring of RP activity in our study cohort.

An unusual finding in the present study was the high incidence of haematological malignancy in our cohort. Five of the ten patients had associated haematological malignancy. The association of RP with MDS was previously described by Hebbar et al, who reported that up to $27 \%$ of their RP patients had concomitant MDS. ${ }^{(8)}$ Two patients in our case series developed MDS after being diagnosed with RP; one of them received azathioprine (50-100 mg) for six months. Table II summarises cases of RP in the literature that were associated with haematological malignancy.

A possible explanation for the pathophysiology underlying the association between RP and lymphoma may be inferred from the pathophysiology of rheumatoid arthritis (RA), as RA is the archetypal autoimmune-mediated inflammatory disease. A meta-analysis of 21 publications demonstrated a twofold increase in lymphoma risk among patients with RA as compared to the general population. ${ }^{(9)}$ In another large case-control study, Baecklund et al showed that RA patients with the highest inflammatory disease activity have a considerably increased risk of lymphoma. ${ }^{(10)}$ That study also concluded that treatment with the most common disease-modifying antirheumatic drugs is in itself not a risk factor for RA-associated lymphomas. Similarly, the use of biologic response modifiers among patients with RA was not significantly associated with an increased risk of malignancy when compared with other disease-modifying antirheumatic drugs or placebos. ${ }^{(11)}$

The link between MDS and RP is presently unclear. A prospective study conducted on MDS patients with autoimmune manifestations did not identify chromosome aberrations that are typically associated with therapy-related MDS. ${ }^{(12)}$ Nonetheless, there is a distinct subset of RP patients who develop haematological malignancies through an unknown pathophysiological process. Future research in this area may include studies examining whether such patients have clonal abnormalities that predispose them to leukaemic transformation.

The increased risk of malignancy among patients with autoimmune disease may be driven by a combination of factors, including sustained inflammatory burden, immunological defects, and personal and environmental exposure such as smoking and some viral infections. ${ }^{(21,22)}$ For example, it has been postulated that sustained excessive salivary and lacrimal gland B-cell stimulation, and impaired B-cell apoptosis in patients with Sjögren's syndrome may lead to tumorigenesis and clonal expansion of B-cells that ultimately leads to the development of lymphomas. ${ }^{(21)}$ The relationship between chronic inflammation and carcinogenesis in RP patients may be elucidated by studying inflammatory markers such as plasma cytokines, lipid peroxides, p53, BAX, cyclins and caspases.

In conclusion, we found an unexpectedly high frequency of RP patients with haematological malignancies in our series. Although MDS has been reported to occur with RP, the association of other haematological malignancies with RP is rare. As the correlation between haematological malignancies 
Original Article

Table II. Summary of cases of relapsing polychondritis (RP) and its association with haematological malignancy, as reported in the literature and the present study.

\begin{tabular}{|c|c|c|c|c|c|c|}
\hline Study & $\begin{array}{l}\text { Gender/ } \\
\text { age of RP } \\
\text { onset (yr) }\end{array}$ & RP clinical feature & $\begin{array}{l}\text { Type of malignancy/ } \\
\text { time of diagnosis }\end{array}$ & RP treatment & $\begin{array}{l}\text { Haematology } \\
\text { treatment }\end{array}$ & Survival/complication \\
\hline Miller et al $\left.\right|^{(13)}$ & $\mathrm{M} / 46$ & Auricular swelling & Hodgkin's lymphoma/6 mth after RP & Steroid & Chemotherapy & $\begin{array}{l}\text { Pneumonia, demise after } 2 \text { courses of } \\
\text { chemotherapy }\end{array}$ \\
\hline Hedayati et al ${ }^{(14)}$ & $M / 63$ & $\begin{array}{l}\text { Saddle nose deformity, deafness, } \\
\text { thickened ears }\end{array}$ & $\begin{array}{l}\text { Nodular NHL (diffuse, mixed } \\
\text { cellular type)/concurrent with RP }\end{array}$ & Nil & Unspecified & $\begin{array}{l}\text { Rheumatoid arthritis, pyoderma } \\
\text { gangrenosum }\end{array}$ \\
\hline Krikorian et al $\left.\right|^{(15)}$ & $\mathrm{M} / 41$ & $\begin{array}{l}\text { Auricular swelling, fever, } \\
\text { odynophagia }\end{array}$ & $\begin{array}{l}\text { Hodgkin's lymphoma (Stage IIIB)/21 } \\
\text { yr before RP; acute leukaemia/3 wk } \\
\text { after RP }\end{array}$ & Steroid & $\begin{array}{l}\text { Chemotherapy/ } \\
\text { haemopoetic } \\
\text { stem cell } \\
\text { transplant }\end{array}$ & $\begin{array}{l}\text { Infection and multisystem failure, demise } \\
5 \mathrm{mth} \text { after diagnosis of acute leukaemia }\end{array}$ \\
\hline Lichauco et al ${ }^{(16)}$ & $F / 41$ & Auricular swelling, joint involvement & $\begin{array}{l}\text { Orbital MALT-type B-cell } \\
\text { lymphoma/12 yr after RP }\end{array}$ & $\begin{array}{l}\text { Steroid, } \\
\text { dapsone }\end{array}$ & Radiotherapy & Nil \\
\hline Yanagi et al $\left.\right|^{(17)}$ & $\mathrm{F} / 60$ & $\begin{array}{l}\text { Auricular swelling, ocular and joint } \\
\text { involvement }\end{array}$ & $\begin{array}{l}\text { Extranodal NHL (splenic diffuse } \\
\text { large B-cell; Stage IIA)/3 yr before } \\
\text { RP }\end{array}$ & $\begin{array}{l}\text { Loxoprofen, } \\
\text { diclofenac, } \\
\text { steroid }\end{array}$ & Unspecified & $\begin{array}{l}\text { Remission of RP for } 7 \mathrm{mth} \text { when the case } \\
\text { was reported, no relapse of lymphoma } \\
\text { reported }\end{array}$ \\
\hline Bochtler et al ${ }^{(18)}$ & $M / 60$ & Auricular swelling & $\begin{array}{l}\text { Chronic lymphocytic leukaemia/ } \\
\text { concurrent with RP }\end{array}$ & Nil & $\begin{array}{l}\text { Chlorambucil/ } \\
\text { prednisone }\end{array}$ & $\begin{array}{l}\text { Auricular swelling, which was resolved } \\
\text { with treatment }\end{array}$ \\
\hline Hall et al $\left.\right|^{(19)}$ & $\mathrm{M} / 72$ & $\begin{array}{l}\text { Diffuse scleritis, arthritis, painful red } \\
\text { vasculitic skin nodules, inflammation } \\
\text { of the pinna and nasal cartilages, } \\
\text { recurrent thrombophlebitis }\end{array}$ & $\begin{array}{l}\text { MDS and non-secretory multiple } \\
\text { myeloma/1 yr after RP }\end{array}$ & $\begin{array}{l}\text { Steroid, } \\
\text { azathioprine }\end{array}$ & Unspecified & $\begin{array}{l}\text { Demise from pneumonia } 4 \mathrm{yr} \text { after } \\
\text { diagnosis of MDS and multiple myeloma }\end{array}$ \\
\hline Castrejón et al $\left.\right|^{(20)}$ & $M / 67$ & $\begin{array}{l}\text { Auricular swelling, unilateral anterior } \\
\text { uveitis }\end{array}$ & $\begin{array}{l}\text { Lymphoplasmacytic lymphoma/ } \\
\text { unknown duration after RP }\end{array}$ & Steroid & Rituximab & $\begin{array}{l}\text { Erythema nodosum, vertebrae } \\
\text { compression fracture, pneumonia; the } \\
\text { patient was alive at the time of publication }\end{array}$ \\
\hline \multirow[t]{5}{*}{ Present study } & $\mathrm{F} / 72$ & Auricular chondritis, scleritis & $\begin{array}{l}\text { Chronic myelomonocytic } \\
\text { leukaemia/30 mth after RP; chronic } \\
\text { myelomonocytic leukaemia later } \\
\text { transformed to acute myeloid } \\
\text { leukaemia }\end{array}$ & Steroid & $\mathrm{Nil}$ & $\begin{array}{l}\text { Demise } 2 \mathrm{yr} \text { after diagnosis of RP, from } \\
\text { acute myeloid leukaemia in blast crisis }\end{array}$ \\
\hline & $M / 60$ & $\begin{array}{l}\text { Urticarial vasculitis, pinna } \\
\text { inflammation, nasal chondritis, } \\
\text { scleritis }\end{array}$ & $\mathrm{MDS} / 60 \mathrm{mth}$ after RP & $\begin{array}{l}\text { Methotrexate, } \\
\text { MMF }\end{array}$ & Prednisolone & $\begin{array}{l}\text { On supportive treatment with blood } \\
\text { transfusion }\end{array}$ \\
\hline & $\mathrm{F} / 50$ & Auricular chondritis, iritis & $\begin{array}{l}\text { Diffuse large B-cell lymphoma/11 yr } \\
\text { before RP }\end{array}$ & $\begin{array}{l}\text { Steroid, MMF } \\
\text { azathioprine, }\end{array}$ & $\begin{array}{l}\text { Haemopoetic } \\
\text { stem cell } \\
\text { transplant }\end{array}$ & In remission \\
\hline & $\mathrm{M} / 69$ & $\begin{array}{l}\text { Scleritis, laryngotracheal } \\
\text { involvement }\end{array}$ & $\begin{array}{l}\text { Monoclonal gammopathy of } \\
\text { unknown significance/12 yr after RP }\end{array}$ & $\begin{array}{l}\text { Steroid, } \\
\text { azathioprine, } \\
\text { cyclosporin }\end{array}$ & Nil & $\begin{array}{l}\text { Demise } 7 \text { yr after diagnosis of RP, from } \\
\text { pneumonia }\end{array}$ \\
\hline & $\mathrm{M} / 52$ & Auricular chondritis & $\mathrm{MDS} / 10 \mathrm{mth}$ after RP & $\begin{array}{l}\text { Colchicine, } \\
\text { prednisolone }\end{array}$ & Prednisolone & Awaiting haemopoetic stem cell transplant \\
\hline
\end{tabular}

F: female; M: male; MALT: mucosa-associated lymphoid tissue; MDS: myelodysplastic syndrome; MMF: mycophenolate mofetil; NHL: non-Hodgkin's lymphoma 
and RP is currently unclear, we recommend that the threshold for haematological/lymphoproliferative screening be lowered in patients with RP.

\section{ACKNOWLEDGEMENT}

We thank our colleagues from the Department of Rheumatology and Immunology, Singapore General Hospital, Singapore, for contributing their cases to this study.

\section{REFERENCES}

1. Chopra R, Chaudhary N, Kay J. Relapsing polychondritis. Rheum Dis Clin North Am 2013; 39:263-76.

2. McAdam LP, O'Hanlan MA, Bluestone R, Pearson CM. Relapsing polychondritis: prospective study of 23 patients and a review of the literature. Medicine (Baltimore) 1976; 55:193-215.

3. Department of Statistics Singapore. Population Trends 2016. Available at: http://www.singstat.gov.sg/publications/publications-and-papers/ population-and-population-structure/population-trends. Accessed March 4, 2017.

4. Kong KO, Vasoo S, Tay NS, Chng HH. Relapsing polychondritis--an Oriental case series. Singapore Med J 2003; 44:197-200.

5. Kent PD, Michet CJ Jr, Luthra HS. Relapsing polychondritis. Curr Opin Rheumatol 2004; 16:56-61.

6. Arundell FD, Haserick JR. Familial chronic atrophic polychondritis. Arch Dermatol 1960; 82:439-40.

7. Pearson CM, Kline HM, Newcomer VD. Relapsing polychondritis. N Eng J Med 1960; 263:51-8.

8. Hebbar M, Brouillard M, Wattel E, et al. Association of myelodysplastic syndrome and relapsing polychondritis: further evidence. Leukemia 1995; 9:731-3.

9. Smitten AL, Simon TA, Hochberg MC, Suissa S. A meta-analysis of the incidence of malignancy in adult patients with rheumatoid arthritis. Arthritis Res Ther 2008; 10:R45.

10. Baecklund E, Iliadou A, Askling J, et al. Association of chronic inflammation, not its treatment, with increased lymphoma risk in rheumatoid arthritis. Arthritis Rheum 2006; 54:692-701.
11. Lopez-Olivo MA, Tayar JH, Martinez-Lopez JA, et al. Risk of malignancies in patients with rheumatoid arthritis treated with biologic therapy: a metaanalysis. JAMA 2012; 308:898-908.

12. Giannouli S, Voulgarelis M, Zintzaras E, Tzioufas AG, Moutsopoulos HM. Autoimmune phenomena in myelodysplastic syndromes: a 4-yr prospective study. Rheumatology (Oxford) 2004; 43:626-32.

13. Miller SB, Donlan CJ, Roth SB. Hodgkin's disease presenting as relapsing polychondritis. A previously undescribed association. Arthritis Rheum 1974; 17:598-602.

14. Hedayati H, Zuzga JJ Jr, Faber DB. Rheumatoid arthritis, relapsing polychondritis, and pyoderma gangrenosum evolving into non-Hodgkin's lymphoma. J Am Osteopath Assoc 1993; 93:240-2, 246-8.

15. Krikorian JG, Palmer-Toy DE. Case records of the Massachusetts General Hospital. Weekly clinicopathological exercises. Case 38-1997. Inflammation of the ears, anemia, and fever 21 years after treatment for Hodgkin's disease. N Engl J Med 1997; 337:1753-60.

16. Lichauco JJ, Lauer S, Shigemitsu HH, et al. Orbital mucosa-associated lymphoid tissue (MALT)-type lymphoma in a patient with relapsing polychondritis. Arthritis Rheum 2001; 44:1713-5.

17. Yanagi T, Matsumura T, Kamekura R, Sasaki N, Hashino S. Relapsing polychondritis and malignant lymphoma: is polychondritis paraneoplastic? Arch Dermatol 2007; 143:89-90.

18. Bochtler T, Hensel M, Lorenz HM, Ho AD, Mahlknecht U. Chronic lymphocytic leukaemia and concomitant relapsing polychondritis: a report on one treatment for the combined manifestation of two diseases. Rheumatology (Oxford) 2005; 44:1199.

19. Hall R, Hopkinson N, Hamblin T. Relapsing polychondritis, smouldering non-secretory myeloma and early myelodysplastic syndrome in the same patient: three difficult diagnoses produce a life threatening illness. Leuk Res 2000; 24:91-3.

20. Castrejón I, Ibáñez M, Vicente E, Luis Steegmann ], Castañeda S. [Relapsing polychondritis associated with a lymphoplasmocytic lymphoma and erythema nodosum]. Reumatol Clin 2007; 3:45-7. Spanish.

21. Szekanecz Z, Szekanecz E, Bakó G, Shoenfeld Y. Malignancies in autoimmune rheumatic diseases - a mini-review. Gerontology 2011; 57:3-10

22. Turesson C, Matteson EL. Malignancy as a comorbidity in rheumatic diseases. Rheumatology (Oxford) 2013; 52:5-14. 